\title{
Az állami tulajdonú gazdasági társaságok pénzügyi teljesitményének mérése, elemzése
}

\author{
Kistóth, Krisztina \\ Allami Számvevöszék \\ kkistoth1@gmail.com
}

Összefoglaló

Az Állami Számvevőszék szakértői a közpénzköltés során a teljesítményelv minél szélesebb körű érvényesülésének elősegítése érdekében az állami tulajdonú gazdasági társaságok pénzügyi teljesítménymérésének kérdéseit vizsgálták. Ezen társaságok teljesítményének mérésére, elemzésére sok szempontból azonos eszközök alkalmazhatók, mint a versenyszféra társaságaira, ugyanakkor indokolt a közszféra specialitásaiból eredő torzítások kiszűrése. Ezért készült el a vállalkozások közgazdasági elemzését célzó pénzügyi mutatóknak egy olyan korrekciós tételekkel kiegészített változata, amely kimondottan e sajátosságok kezelését célozta. A korrigált mutatók teszteléséhez egy 148 fős gazdasági társasági körre készítettünk elemzést, amelynek főbb megállapításait mutatja be a cikk. Az állami tulajdonú gazdasági társaságok eltérő feltételei, működése vagy kockázatai, a kapcsolódó tulajdonosi feladatok ellátása, a tulajdonosi kontroll szempontjából különböző eszközöket, prioritásokat igényelhet. A cikkben kísérletet teszünk a gazdasági társaságok korrigált pénzügyi mutatói szerint történő viszonylag homogén csoportok, portfóliók képzésére, amely a pénzügyi adottságok és teljesítmény szerinti megkülönböztetett kezelést segítheti. A csoportképzés felhívhatja a figyelmet a kritikus gazdálkodási tényezőkre, kockázatokra, de ugyanakkor erősségekre is. Ezzel a portfóliók kialakítása jó alapot biztosíthat a társaságok hatékony tulajdonosi menedzsmentjéhez.

KuLcsszavaK: teljesítménymenedzsment, pénzügyi teljesítmény, teljesítménymérés, klaszterképzés, portfóliómenedzsment

JEL-ко́рок: C52, H11, H40, L29, L39

DOI: https://doi.org/10.35551/PSZ_2021_k_2_2 
A jól irányított szervezeti modell megvalósítását a szervezeti teljesítménymenedzsmentrendszer megvalósítása és működtetése szolgálja, ez adja a teljesítménymenedzsment fontosságát. A teljesítménymenedzsment kiterjed a szervezet egészére, átfedi azt a tervezéstől, az elszámoltathatóságon és a megvalósításon keresztül, egészen a tanulás és a megerősítés támogatásáig. A teljesítménymenedzsment célja, hogy biztosítsa a szolgáltatás ellátását, az erőforrások hatékony allokálását, javítsa a szervezet feladatellátási teljesítményét és a források hatásos felhasználását, támogassa a tanulást annak érdekében, hogy a munkatársak új ismeretekre tegyenek szert a feladatellátás hatékonyságának emelése érdekében, valamint fejlessze a feladat ellátásában résztvevő szervezetek és egységeik kapacitását (Veresné, 2017). Összefoglalva: a teljesítménymenedzsment a szervezet teljesítményének javításával kapcsolatos tevékenységek összesége [Kaiser T. (szerk.), 2014.]

\section{A PÉNZÜGYI TELJESÍTMÉNY MÉRÉSE}

A teljesítménymenedzsment keretében a célkijelölés és a tervezés során a vezetők a szervezet teljesítményére vonatkozó követelményeiket konkretizálják, majd mérési rendszereket hoznak létre annak érdekében, hogy a teljesítmény különböző elemeiről folyamatosan információt gyüjtsenek. Végül a beszámolási rendszer adja meg a keretét a teljesítményről való rendszeres visszacsatolásnak. A teljesítménymenedzsment az aktuális eredmények tanulmányozását és összevetését végzi a tervezett, elvárt eredményekkel. Az aktuális és a tervezett eredmények jelentős eltérése esetén pedig korrekciós lépéseket kell bevezetni (Szakács, 2012).

A szervezeti teljesítmény egyik igen fontos területe a pénzügyi teljesítmény. A vállalati gazdálkodásban ezalatt szűkebb értelemben azt értik, hogy a vállalat teljesítette-e, illetve megvalósítja-e pénzügyi céljait. Ugyanakkor a pénzügyi teljesítmény tágabb értelemben azt jelenti, hogy a szervezet pénzügyileg egészséges, ennek keretében likviditása folyamatosan biztosított, követeléseinek és kötelezettségének lejárati szerkezete összhangban van, eladósodottsága a saját forrásaihoz képest biztonságos mértékü (Pulay, Simon, 2020).

A pénzügyi teljesítmény méréséhez a - közgazdaságtani szakirodalomból ismert - pénzügyi elemzésekhez alkalmazott mutatók a legalkalmasabbak, amelyek jellemzően számviteli adatokra támaszkodnak. A mutatók az elemzések szempontjai szerint öt csoportba sorolhatók, amelyek a likviditási, adósság- és hitelképességi, jövedelmezőségi, hatékonysági, és piaci mutató csoportok (PTE-KTK, 2018).

A likviditási mutatók a vállalatok fizetőképességét, fizetőkészségét írják le, azt mutatják, hogy a vállalat a rövid lejáratú kötelezettségeinek eleget tud-e tenni. Az adósság- és hitelképességi ráták a hitelvisszafizetési képességet jelzik. Ezen belül kerül elemzésre a tőkeszerkezet, hiszen annál nagyobb kockázatot vállalnak a tulajdonosok, minél nagyobb arányt képviselnek az összes eszközön belül. A jövedelmezőségi vagy más néven profitabilitási mutatók mérik, hogy egy vállalat milyen mértékben képes nyereséget, profitot realizálni a rendelkezésére álló eszközökkel (PT-KTK, 2018). Cikkünkben e három csoportból választottunk mutatókat.

A közszférában a teljesítménymenedzsment kezdeti lépései Magyarországon Magyary Zoltán Közigazgatás-fejlesztési programjához köthetők. Egyértelművé vált, hogy a vállalkozások világában alkalmazott teljesítménymenedzsment a közszféra intézményeiben és szervezeteinél is alkalmazható. Az egyéni teljesítményértékelés elterjedése már korábban megtörtént, azonban a szervezeti, tevékenységszintű teljesítménymenedzsment még sok fejlesztési, fejlődési területet tartogat.

A ,jól irányított állam” feltétele a jól irányított állami szervezetek működtetése. A szerve- 
zetek vezetőinek a jó irányítási rendszerek müködtetése iránti elkötelezettsége hozzájárul a szervezet küldetése megvalósításához, a szervezeti folyamatok teljesítőképességéhez. (Domokos, Wertherné, 2020). „A jó kormányzás fejlesztésének, valamint kiegyensúlyozott jövőbeli fejlödése megalapozásának záloga a közszféra teljesitményorientált müködtetése" (Domokos, Wertherné, 2020, 16. oldal). Így, a teljesítménymenedzsment kialakítása és mủködtetése a közszférában is hozzáadott értéket teremt, amelyhez a világos szervezeti célok és az ezek teljesülését nyomon követő mérési rendszer szükséges.

A pénzügyi teljesítmény értelmezése ugyanakkor a közszférában az üzleti szférához képest sajátosságokat mutat. A közszféra gazdálkodását elsődlegesen nem a nyereség maximalizálása vezérli. „A szervezettel szemben elvárt magatartás ugyanis a társadalmi hasznosság növelése, a közjó szolgálata, amelyet nonprofit jelleggel, feladatellátási kötelezettség mellett hajt végre. Ezért a vezetö elsödleges célja a jogszabályok és egyéb kötelmek által elöirt tevékenységek ellátása." (Domokos et al., 2015, 14. oldal). Ugyanakkor a sajátosságok mellett az üzleti szférával való azonosságot jelenti, hogy a közpénzügyi gazdálkodás pénzügyi teljesítménye egyfelől jelenti a kitűzött pénzügyi célok teljesítését, másfelől a pénzügyi helyzet kiegyensúlyozottságát (Pulay, Simon, 2020).

A teljesítménymenedzsment és a teljesítménymérés elválaszthatatlan fogalmak a közszféra területén is. A mennyiségi mutatókra épülő teljesítménymérések során mérőszámok és mérési, elemzési technikák kerülnek kialakításra (Iványos, Sándorné, 2016). Az üzleti szférában alkalmazott mérési mutatók azonban változatlan formában nem alkalmazhatók, a közszféra sajátosságainak kezeléséhez a mutatók korrigálására van szükség. Természetesen a pénzügyi teljesítmények mellett további teljesítménydimenziók elemzése is elengedhetetlen, azonban jelen cikkünk fókuszát a pénzügyi mutatók jelentik.
Az elemzéseket az Állami Számvevőszék szakértői végezték. A korrigált pénzügyi mutatók kialakítása Pulay Gyula, Borbély Tamás és Orosz Diána munkája. A portfólióképzés módszertanának kidolgozója Melcher István, Novák Márta és Nagy László voltak, akik a korrigált mutatók, valamint a klaszterek szerinti elemzéseket is készítették.

\section{AZ ÁLLAMI TULAJDONÚ GAZDASÁGI TÁRSASÁGOK KORRIGÁLT PÉNZÜGYI MUTATÓl}

A vállalati gazdaságtanban általánosan használt - az 1. táblázat szerinti - pénzügyi mutatókat tekintettük kiindulópontnak.

Tekintettel az állami tulajdonban álló gazdasági társaságok sajátosságaira (a kezelt, illetve üzemelésre átvett vagyon magas aránya a saját vagyonhoz képest; a fejlesztések meghatározó részének támogatásból történő megvalósítása és ennek sajátos elszámolásai stb.), indokoltnak tartottuk a mutatószámokat korrigálni, amely a következő alapelvek szerint történt.

A befektetett eszközök között és ezzel együtt a kötelezettségek között nyilvántartott, vagyonkezelésbe kapott eszközök értéke nem a kötelezettségek között került figyelembevételre, hanem a saját tőkénél. A vagyonkezelésbe kapott eszközök átsorolása a saját tőke közé az érintett vagyonelemekkel való gazdálkodás tulajdonságai miatt került sor. A vagyonkezelt eszközöket jellemzően a tulajdonos, alapító bocsátja a gazdasági társaság rendelkezésére, de több esetben előfordult, hogy ezt a társaság működési területén illetékes helyi önkormányzat teszi. A vagyonkezelésbe kapott eszközök után elszámolt értékcsökkenési leírásnak megfelelően visszapótlási kötelezettség terheli a gazdasági társaságot, ugyanakkor az érintett eszközök nettó értékének megfelelő összeg nem valós kötelezettsége. Amennyiben megszűnik a 


\section{AZ ELEMZÉS MUTATÓINAK KIALAKÍTÁSAKOR FIGYELEMBE VETT PÉNZÜGYI MUTATÓK}

\begin{tabular}{|c|c|c|c|}
\hline Mutató típusa & Mutató megnevezése & Számitás & Elvárt érték \\
\hline \multirow[t]{2}{*}{$\begin{array}{l}\text { Likviditást, fizetési } \\
\text { képességet jellemző mutatók }\end{array}$} & Likviditási ráta & $\begin{array}{l}\text { Forgóeszközök / } \\
\text { RLK }\end{array}$ & 1,0-nél nagyobb \\
\hline & Eladósodottsági mutató & $\begin{array}{l}\text { Kötelezettségek / } \\
\text { Források összege }\end{array}$ & $\begin{array}{l}\text { 0,5-nél kisebb, csökkenő } \\
\text { értékek az elvártak }\end{array}$ \\
\hline \multirow[t]{3}{*}{ Tőkeszerkezeti mutatók } & Tőkefeszültségi mutató & Kötelezettségek / ST & $\begin{array}{l}\text { 1,0-nél kisebb, csökkenő } \\
\text { értékek az elvártak }\end{array}$ \\
\hline & Tőkeellátottsági mutató & ST / Források & 0,5 vagy nagyobb érték \\
\hline & Sajáttőke-növekedési mutató & ST / JT & 1,0-nél nagyobb érték \\
\hline Jövedelmezőségi mutató & ROE & MSZE vagy AE/ ST & Pozitív, növekvő érték \\
\hline
\end{tabular}

Megjegyzés: RLK=rövid lejáratú kötelezettségek; ST=saját tőke; ROE=Return on Equity (vagyonarányos nyereség); MSZE=mérleg szerinti eredmény; AE=adózott eredmény; JT=jegyzett tôke

Forrás: Takács, 2015 alapján, saját szerkesztés

vagyonkezelés a hosszú lejáratú kötelezettségek közül is kivezetésre kerül értékük. A gazdasági társaság a vagyonkezelésébe adott vagyonnal is gazdálkodik, tehát a vagyonarányos jövedelmezőségét nem reálisan mutatná, ha nyereségét csak a saját tőkéjéhez viszonyítanánk.

A A pénzeszközként elszámolt és a kötelezettségek között nyilvántartott, elszámolásköteles pályázati előlegek a pénzügyi mutatókban semlegesítésre kerültek, tehát nem képezték a számítás részét. Ennek oka, hogy sokszor jelentős összegű pályázati források - amelyeket a gazdasági társaságok nem költhetnek szabadon, hanem kizárólag a meghatározott célokra - jelentősen torzítják az érintett vállalatok likviditási, tőkeszerkezeti mutatóit, így azok nem adnak valós képet a gazdálkodásról.

\A kötelezettségek között nyilvántartott tőkeemelés nem a kötelezettségek között, hanem a saját tőkénél került figyelembevételre. Az alapítók (tulajdonosok) a gazdasági társaságok tőkéjét több esetben megemelték, ami jellemzöen a jegyzett tőke vagy tőketartalék sorokon jelent meg a mérlegekben. Ugyanakkor a bejegyzés pillanatáig a tőkeemelési célú átutalás a rövid lejáratú kötelezettségek között került kimutatásra, és a következő üzleti évben sorolták át a saját tőke valamelyik sorára. Emiatt ezt az átsorolást már a bejegyzés előtt átvezettük a pénzügyi mutatók korrigált változatain, hogy a valós tulajdonságának megfelelően saját tőkeként szerepeljenek az elemzésben.

A korrigált pénzügyi mutatók számítási módját a 2. táblázat ismerteti.

LiKVIDITÁsI RÁTA: a forgóeszközök és a rövid lejáratú kötelezettségek arányát fejezi ki, ez a legtágabb értelemben vett likviditási mutatószám. A likviditási ráta korrigált változata semlegesíti azokat a rövid lejáratú kötelezettségek között kimutatott, elszámolás-köteles pályázati előlegeket, amelyeket a gazdálkodó már jóváírt a pénzeszközök között, valamint nem veszi figyelembe a rövid lejáratú kötelezettségek sorokon elszámolt, be nem jegyzett tőkeemeléseket. Elvárt az 1,0-től jelentősen magasabb érték.

EladósodotTsági mutató: szintén a likviditást és fizetőképességet jellemzi, de az eladósodottság aspektusából. Minél nagyobb egy gazdálkodó működésében a kötelezettségek aránya 


\section{AZ ELEMZÉS SORÁN KIDOLGOZOTT ÉS ALKALMAZOTT, KORRIGÁLT PÉNZÜGYI MUTATÓK}

\begin{tabular}{|c|c|c|}
\hline Mutató típusa & $\begin{array}{l}\text { Mutató } \\
\text { megnevezése }\end{array}$ & Számítás \\
\hline \multirow[t]{2}{*}{$\begin{array}{l}\text { Likviditást, fizetési } \\
\text { képességet jellemző } \\
\text { mutatók }\end{array}$} & Likviditási ráta (korrigált) & $\begin{array}{l}\text { (Forgóeszközök - Pályázati előleg / } \\
\text { (RLK - RLK között elszámolt pályázati előleg - Be nem jegyzett } \\
\text { tőkeemelés) }\end{array}$ \\
\hline & $\begin{array}{l}\text { Eladósodottsági mutató } \\
\text { (korrigált) }\end{array}$ & $\begin{array}{l}\text { (Kötelezettségek - Vagyonkezelt eszközök értéke - Pályázati előleg - } \\
\text { Be nem jegyzett tôkeemelés) / } \\
\text { (Források összege - Pályázati előleg) }\end{array}$ \\
\hline \multirow[t]{3}{*}{ Tőkeszerkezeti mutatók } & $\begin{array}{l}\text { Tőkefeszültségi mutató } \\
\text { (korrigált) }\end{array}$ & $\begin{array}{l}\text { (Kötelezettségek - Vagyonkezelt eszközök értéke - Pályázati előleg } \\
\text { - Be nem jegyzett tőkeemelés) / (ST + Be nem jegyzett tőkeemelés + } \\
\text { Vagyonkezelt eszközök értéke) }\end{array}$ \\
\hline & $\begin{array}{l}\text { Tőkeellátottsági mutató } \\
\text { (korrigált) }\end{array}$ & $\begin{array}{l}\text { (ST + Be nem jegyzett tôkeemelés + Vagyonkezelt eszközök értéke) / } \\
\text { (Források - Pályázati előleg) }\end{array}$ \\
\hline & $\begin{array}{l}\text { Sajáttőke-növekedési } \\
\text { mutató (korrigált) }\end{array}$ & $\begin{array}{l}\text { (ST + Be nem jegyzett tőkeemelés) / (JT+ Be nem jegyzett } \\
\text { tőkeemelés) }\end{array}$ \\
\hline Jövedelmezőségi mutató & ROE (korrigált) & $\begin{array}{l}\text { MSZE vagy AE / (ST + Vagyonkezelt eszközök értéke + Be nem } \\
\text { jegyzett tőkeemelés) }\end{array}$ \\
\hline
\end{tabular}

Forrás: saját szerkesztés

az összes forráshoz képest, annál nagyobb az idegen forrásból történő finanszírozás (azaz az eladósodottság) aránya, és a fizetési nehézségek kialakulásának veszélye, hiszen az idegen forrásokat előbb-utóbb vissza kell fizetni. A mutató korrigálásra került a hosszú lejáratú kötelezettségek között kimutatott vagyonkezelt eszközök értékével, és a rövid lejáratú kötelezettségek között kimutatott be nem jegyzett tőkeemelés mértékével. A kötelezettségek között elszámolt pályázati előleggel mind a számlálót, mind a nevezőt csökkentettük. Ajánlatos, hogy az érték ne haladja meg az 50 százalékot: a csökkenő tendencia a kedvező.

TőKefeszüLTSÉgi muTATó: a finanszírozás stabilitásáról ad tájékoztatást a kötelezettségek és a saját tőke összehasonlításával. A korrigált változatban a hosszú lejáratú kötelezettségek között kimutatott vagyonkezelt eszközök értéke és a be nem jegyzett tőkeemelés értéke átsorolásra került a saját tőke közé. A kötelezettségek között elszámolt pályázati előleggel a számlálót csökkentettük. Ajánlott, hogy az érték ne haladja meg a 100 százalékot, valamint csökkenő tendencia a kívánatos.

TőKeELLÁtotTSÁgI MUTATÓ: a tőke szerkezetét jellemzi, és a vagyoni helyzet általános bemutatására alkalmas. E mutató kiszámításakor is alkalmazásra kerülnek korrekciós tényezők. A saját tőke értékéhez hozzáadtuk a hosszú lejáratú kötelezettségek között kimutatott vagyonkezelt eszközök értékét és a kötelezettségek között elszámolt be nem jegyzett tőkeemelést. A kötelezettségek között elszámolt pályázati előleggel mind a számlálót, mind a nevezőt csökkentettük. Ajánlatos, hogy az értékek növekvő tendenciát mutassanak.

SAJÁTTŐKE-NÖVEKEDÉSI MUTATÓ: a saját tőke és a jegyzett tőke arányának alakulását mutatja, hogy a saját tőke teljes, akár többévnyi nö- 
vekménye mekkora. Mind a nevező, mind a számláló korrigálásra került a befizetett, de még be nem jegyzett tőkeemeléssel. Kedvező, amennyiben a mutató értéke meghaladja az 1-et. Az 1-nél kisebb mutató tőkevesztésre utal, amely tartós esetben a veszteséges gazdálkodás következtében a tőke feléléséhez vezet.

ROE: a tőkearányos jövedelmezőséget kifejező mutatószám, a jövedelmezőség mérésére egyik leggyakrabban alkalmazott mutató. A ROE a mérleg szerinti, illetve az adózott eredményt hasonlítja össze a saját tőkével, így megmutatja, hogy a tulajdonosok által rendelkezésre bocsátott, valamint a gazdálkodás során felhalmozott vagyon mekkora eredményt produkált. Az ÁSZ elemzése során a ROEmutató értéke a saját tőke mellett a vagyonkezelt eszközök értékét és a be nem jegyzett tökeemelést is tartalmazza. Elvárt a mutatószám értékének pozitív tartományban tartózkodása, a mutató emelkedő tendenciája a kedvező.

A korrigált tőkefeszültségi mutató és ROEmutatók negatív saját tőke esetén nem kerültek meghatározásra. Előbbi esetben azért, mert negatív tőkefeszültség-értéket nem értelmezünk, utóbbi tekintetében pedig azért, mert a negatív saját tőke negatív adózott eredménynyel párosulva pozitív ROE-mutatót eredményezne, amely mutató így elvesztené valós jelentéstartalmát.

A mutatók alkalmazásával több év adatainak összevont elemzése indokolt, annak érdekében, hogy az évek adatait befolyásoló egyedi tételek hatása csökkenjen. A mutatók teszteléséhez 5 éves időszakot (2015-től 2019ig) választottuk, és a korrigált mutatókat 148 többségi állami tulajdonú gazdasági társaság beszámoló adatai alapján számítottuk ki. Az értékelt 5 év vonatkozásában elemeztük a mutatók átlagát és szóródását. Az elemzéshez elvégeztük a gazdasági társaságok tipizálását, a társaságok tevékenysége, mérete, közfeladatellátása szerint csoportokat képezve. A több év korrigált mutatók eredményeinek elemzé- sével összefüggések voltak azonosíthatók a társaságok egyes jellemzői (tevékenység, méret, közfeladat-ellátás) és a gazdálkodásuk pénzügyi mutatói alapján értékelt gazdálkodásukról. A pénzügyi mutatók főbb, leíró statisztikai jellemzőit tartalmazza a teljes sokaságra vonatkozóan a 3. táblázat.

A 148 társaság korrigált mutatóinak kiszámítása megmutatta, hogy a likviditási ráta és ROE-mutatók értékei széles tartományon belül, nagymértékben szóródtak, és jelentős volt a szórása a tőkefeszültségi és a sajáttőke-növekedési mutatónak is. Az eladósodottságot és tőkeellátottságot mérő mutatóknak lényegesen kisebb a relatív szórása, értékeik viszonylag szűk tartományban mozogtak. A tesztelés rávilágított, hogy a szélsőséges értékek jelentősen torzítják a pénzügyi mutatók alapján tehető megállapításokat, elfedik az elemzett társaságok legnagyobb részére jellemző folyamatokat. Ezért a számításokat nemcsak a teljes sokaságra vonatkozóan volt indokolt elvégezni, hanem a szélsőséges értékektől megtisztított sokaságokra nézve is.

\section{A TORZÍTÓ TÉTELEK KISZÜRÉSE}

A kiválasztott gazdasági társaságok között léteztek olyanok, amelyek feladataikból, rendeltetésükből, különleges helyzetükből fakadóan kiugró pénzügyi mutatókkal rendelkeztek, ezzel nagy súlyuknál fogva erősen torzítva a csoportok átlagos teljesítményéről alkotott képet. Erre való tekintettel indokolt volt a társaságok szélsőséges értékeinek kiszűrése a mutatók elemzésekor.

Az általunk alkalmazott eljárásban a tisztítás az egyes pénzügyi mutatók esetében külön-külön történt, mutatónként hozva létre a sokaságokat. Előbb kiszámítottuk a teljes sokaság alsó és felső kvartilisát, és ezek különbségét, azaz az úgynevezett interkvartilis-terjedelmet. Az alsó kvartilistól lefelé, illetve a felső kvartilistól felfelé az interkvartilis-terjedelem háromszoro- 
3. táblázat

\section{AZ ELEMZETT GAZDASÁGI TÁRSASÁGOK PÉNZÜGYI MUTATÓINAK FÖBB STATISZTIKAI JELLEMZŐI (2015-2019)}

\begin{tabular}{|l|r|r|r|r|r|r}
\hline Megnevezés & $\begin{array}{c}\text { Likviditási } \\
\text { ráta }\end{array}$ & $\begin{array}{c}\text { Eladósodott- } \\
\text { sági mutató }\end{array}$ & $\begin{array}{c}\text { Tókefeszillt- } \\
\text { ségi mutatón }\end{array}$ & $\begin{array}{r}\text { Tókeellá- } \\
\text { tottsági } \\
\text { mutató }\end{array}$ & $\begin{array}{r}\text { Sajáttóke- } \\
\text { növekedési } \\
\text { mutató }\end{array}$ & R0E \\
\hline Átlag & 19,83 & 0,26 & 4,14 & 0,53 & 18,27 & 0,02 \\
\hline Szórás & 189,48 & 0,28 & 23,26 & 0,35 & 52,26 & 0,54 \\
\hline Medián & 2,55 & 0,16 & 0,28 & 0,61 & 3,86 & 0,02 \\
\hline Minimum & 0,05 & 0,00 & 0,00 & $-2,85$ & $-31,56$ & $-6,48$ \\
\hline Maximum & 4677,42 & 3,25 & 302,91 & 1,00 & 457,47 & 8,78 \\
\hline Terjedelem & 4677,37 & 3,25 & 302,91 & 3,85 & 489,03 & 15,26 \\
\hline Relatív & 955,47 & 109,66 & 562,27 & 65,92 & 286,06 & 2356,58 \\
\hline szórás (\%) & & & & & & \\
\hline
\end{tabular}

Megjegyzés: A likviditási ráta, eladósodottsági mutató és tőkefeszültségi mutató értékei negatív számok nem lehetnek, a legkisebb lehetséges, értelmezett érték a nulla. A tőkeellátottsági mutató és a sajáttőke-növekedési mutató az esetleges negatív sajáttőkeértékek, a ROE-mutató értékei a negatív adózott eredmény miatt a negatív tartományban is előfordultak.

Forrás: elemzett gazdasági társaságok számviteli beszámolói alapján saját szerkesztés

sa mértékét meghaladóan kívül eső elemektől tisztítottuk meg a sokaságot. Az egyes pénzügyi mutatók esetében a tisztítás során kiesett szélsőséges értékek aránya jelentősen különbözött. A kiesett értékek aránya a legmagasabb ROE-mutató esetében volt, de még itt sem érte el a 16 százalékot. Következésképpen minden mutatóhoz tartozó tisztított sokaság megfelelő mennyiségü adatot tartalmazott a statisztikai elemzések elvégzéséhez. A tisztított sokaságban maradt tételek arányát az elemzési eredményeknél mindenhol feltüntettük. A tisztított sokaságok pénzügyi mutatóinak főbb leíró statisztikai jellemzőit a 4. táblázat foglalja össze.

A szélsőséges értékektől való tisztítás után jelentősen szűkült a pénzügyi mutatók terjedelme. A kizárt értékek aránya a teszt esetében a ROE-mutató esetében volt magas (15,7 százalék). Ugyanakkor e mutatót leszámítva az eredeti értékek több mint 89 százaléka az egyes tisztított sokaságok részét képezte. Ez azt je- lenti, hogy az elemzett esetek legnagyobb része egy szűk tartományon belül mozgott, tehát az egyes pénzügyi mutatókhoz tartozó tisztított sokaságokra tett megállapítások a gazdasági társaságok döntő többségére nézve helytállóak, sőt pontosabbak voltak, mint a teljes sokaságra tett azon megállapítások, amelyek a nem a normál gazdálkodási folyamatokból adódó kiugró értékek miatt torzítottak.

$\mathrm{Az}$ adattisztítás leginkább a likviditási ráta esetében volt indokolt. A mutató átlagos értéke a teljes sokaságban mért 19,83-ról jelentősen, 3,39-re csökkent. Ez pedig annak a következménye volt, hogy a szélsőséges likviditási rátával rendelkező gazdasági társaságok mindegyike a felső határon lógott ki a sorból, azaz sokkal magasabb volt a likviditásuk, mint a többieknek. A konkrét beszámolók áttekintése azt az eredményt hozta, hogy ebbe a körbe tartoztak a pénzügyi tevékenységet végző gazdasági társaságok, amelyeknek értelemszerüen sokkal nagyobb likviditással kell rendelkezni- 
4. táblázat

\section{A PÉNZZ̈GYI MUTATÓK FŐBB STATISZTIKAI JELLEMZÖI A HOZZÁJUK TARTOZÓ TISZTÍTOTT SOKASÁGOKBAN (2015-2019)}

\begin{tabular}{|l|c|c|c|c|c|c|}
\hline Megnevezés & $\begin{array}{c}\text { Likviditási } \\
\text { ráta }\end{array}$ & $\begin{array}{c}\text { Eladósodott- } \\
\text { sági mutatón }\end{array}$ & $\begin{array}{c}\text { Tókefeszilt- } \\
\text { ségi mutató }\end{array}$ & $\begin{array}{c}\text { Tókkeellá- } \\
\text { tottsági } \\
\text { mutató }\end{array}$ & $\begin{array}{c}\text { Sajáttóke- } \\
\text { növekedési } \\
\text { mutató }\end{array}$ & R:0E \\
\hline Átlag & 3,39 & 0,25 & 0,49 & 0,54 & 5,88 & 0,03 \\
\hline Szórás & 3,20 & 0,25 & 0,64 & 0,31 & 7,35 & 0,07 \\
\hline Medián & 2,32 & 0,16 & 0,22 & 0,61 & 3,28 & 0,02 \\
\hline Minimum & 0,05 & 0,00 & 0,00 & $-0,49$ & $-9,33$ & $-0,18$ \\
\hline Maximum & 16,69 & 1,05 & 2,97 & 1,00 & 34,57 & 0,24 \\
\hline Terjedelem & 16,65 & 1,05 & 2,97 & 1,49 & 43,90 & 0,42 \\
\hline Relatív szórás (\%) & 94,27 & 99,07 & 131,23 & 58,49 & 125,02 & 233,55 \\
\hline Kizárt értékek & 7,72 & 0,54 & 10,49 & 0,27 & 9,59 & 15,66 \\
\hline aránya (\%) & & & & & & \\
\hline
\end{tabular}

Forrás: az elemzett gazdasági társaságok számviteli beszámolói alapján, saját szerkesztés

ük, mint a termelő vagy szolgáltató vállalkozásoknak. Mellettük ide tartoztak még olyan gazdasági társaságok is, amelyek uniós és kisebb mértékben hazai támogatások közvetítésében működtek közre. E célból az általuk meghirdetendő, lebonyolítandó pályázatok forrását előre megkapták, de azok felhasználására csak fokozatosan került sor. Amikor egy cég a saját fejlesztésére elnyert pályázathoz kapott előleget, akkor azt a likviditás számításakor semlegesítettük, itt azonban nem saját fejlesztésekhez adott előlegekről, hanem másoknak tovább közvetítendő támogatások megelőlegezéséről volt szó.

A sajáttőke-növekedési mutató átlagos értéke tisztítást követően kevesebb, mint harmadára esett vissza. A kizárt esetek - egy kivétellel - mind a tőketöbblettel rendelkezők kategóriájába estek, vagyis ahol a korrigált saját tőke több tízszeresével/-százszorosával meghaladta a korrigált jegyzett tőkét, tőkeemelés, nyereséges gazdálkodás és jelentős tartalékok következtében. A kizárt esetek 57 százalékában a társasá- got a minimális jegyzett tőkével, alapították, 14 százalék jegyzett tőkéje a 4 és 10 millió forint közé esett, míg csak a 28 százalék jegyzett tőkéje haladta meg a 10 millió forintot. A kis értékű jegyzett tőke pedig alacsony jövedelmezőség mellet könnyen megsokszorozható, nagy termelési érték esetén.

A tőkefeszültségi mutató átlagos értéke a tisztítást követően kevesebb, mint egynyolcadára esett vissza a mutatónak a teljes sokaságban mért átlagos értékéhez képest, amely jelentős javulást takar. A javulás, valamint a kizárt értékek tíz százalékot meghaladó aránya mögött a gazdasági társaságok 20 százaléka állt, amelyek 47 százalékának (14 társaság) tőkefeszültség-mutatója átlagban négy évben is szélsőségesen kedvezőtlen értéket vett fel.

A ROE-mutató átlagos értéke a teljes sokaságban és a tisztítás után is közel azonos értéket vett fel. A teljes sokaságból a kizárt arány meghaladta a 10 százalékot, ahol a vagyonarányos jövedelmezőség szélsőséges értéket vett fel, de ezek kiegyenlítették egymást. A sokaságban 
szereplő mutatóértékek közül 65 kiugróan alacsony és 47 kiugróan magas értéket vett fel. A kiszűrt ROE-mutatóval rendelkező társaságok több esetben mutattak alacsony sajáttőkeértéket, amelyet egyrészt alacsony jegyzett tőke és/vagy a veszteséges gazdálkodás következtében felélt saját tőke jellemzett.

A sajáttőke-növekedés, a tőkefeszültség és a ROE-mutatók vonatkozásában a három vagy több kiszürt tétellel rendelkező társaságok csoportjának többsége közös jellemzőjeként írható le az alacsony tőkeellátottság. A teljes sokaság eladósodottsági és tőkeellátottsági mutatójának az értékét a tisztítás alig változtatta.

\section{A KORRIGÁLT MUTATÓK ELEMZÉSÉNEK EREDMÉNYEI}

A teszteléshez választott 148 gazdasági társaság elemzése során több érdekes összefüggést tártunk fel. A tevékenység alapján végzett elemzéshez a gazdasági társaságokat csoportokba soroltuk. A humán elnevezésű csoportba soroltuk az egészségügyi, az oktatási, valamint a szociális tevékenységet. Az állami tulajdonú gazdasági társaságok az állam működésével közvetlenül összefüggő feladatokat látnak el, ily módon sokszor egyedi, tevékenységet végeznek. Ennek következtében nem minden társaságot lehetett a tevékenysége szerint ágazatba sorolni, hanem alkalmaznunk kellett egy egyéb kategóriát is, valamint egy „projektmegvalósító szervezet” kategóriát. A projektmegvalósító szervezetek esetében valamilyen projekt végrehajtása jelenti a végzett tevékenységet, amely speciális finanszírozást igényel. Az egyedi feladatokat ellátó szervezetek az egyéb kategóriába kerültek, ahol az összes társaság 7,4 százalék, tehát kevesebb, mint tizede található. A társaságok tevékenységcsoportok közötti megoszlását az 1 . ábra mutatja.

A gazdasági társaságokat tevékenységi területtől függetlenül kedvező likviditási és - a pro- jektmegvalósító szervezeteket kivéve - kedvező eladósodottsági szint jellemezte. A legkedvezőbb likviditási, eladósodottsági, tőkefeszültségi és -ellátottsági mutatókkal a pénzügyi tevékenységet folytató társaságok rendelkeztek.

A tőkefeszültségi mutatókban ugyanakkor jelentős különbségek azonosíthatók a gazdasági társaságok tevékenységi terület szerint kialakított csoportjai között, amelyek azonban a szélsőséges értékek kizárását követően jelentősen mérséklődtek, az értékek számottevően javultak, az elvárt tartományba kerültek. Mindez azt jelzi, hogy a pénzügyi mutatószámok átlagos értékeinek tevékenységi területek szerinti különbözőségét önmagában nem a tevékenység jellege okozza, hanem az, hogy egyes tevékenységi területeken (például projektmegvalósító szervezetek, szállítás és közlekedés, kutatás- és infrastruktúra-fejlesztés, humánszolgáltatások stb.) magas arányban vannak szélsőséges értékű mutatószámokkal rendelkező társaságok.

A gazdasági társaságok jövedelmezősége - a pénzügyi tevékenység kivételével - a különböző tevékenységi területeken ugyan pozitív, de alacsony szintet mutatott. Tevékenységi területtől függetlenül a szélsőségesen magas vagy alacsony vagyonarányos jövedelmezőségi mutatók jellemzően az alacsony tőkeellátottságra voltak visszavezethetők.

A méret szerinti elemzéshez a gazdasági társaságok besorolásának alapja az adott üzleti év végi mérlegföösszeg és az átlagosan foglalkoztatottak száma volt. A besorolás szabályai pedig A kis- és középvállalkozásokról, fejlődésük támogatásáról szóló 2004. évi XXXIV. törvény (kkv-törvény) rendelkezései szerint kerültek meghatározásra. Bár az elemzett gazdasági társaságok tulajdonosi szerkezetük miatt nem tekinthetők kkv-knak, a jogszabályban megfogalmazott besorolás alkalmazható az elemzés során. A társaságok csoportba került arányát zárójelben tüntettük fel 


\section{AZ ELEMZETT GAZDASÁGI TÁRSASÁGOK TEVÉKENYSÉG SZERINTI MEGOSZLÁSA, SZÁZALÉK}
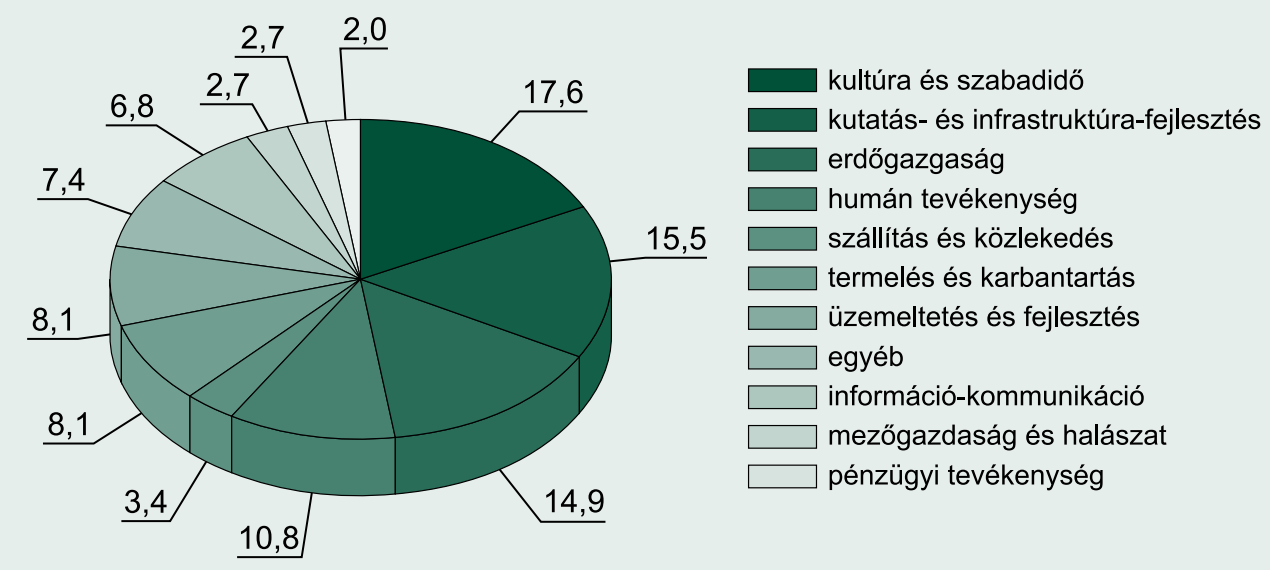

Forrás: saját szerkesztés

(5. táblázat). Mikrovállalkozás volt az a vállalkozás, amely 10 fónél kisebb és/vagy a mérlegföösszege legfeljebb 2 millió eurónak megfelelő forintösszeg (3,38 százalék). Kisvállalkozás, ha 50 fonnél kisebb és/vagy a mérlegföösszege legfeljebb 10 millió eurónak megfelelő forintösszeg (14,19 százalék). Közepes besorolást kapott a vállalkozás, ha 250 fönél kisebb és/vagy a mérlegföösszege legfeljebb 50 millió eurónak megfelelő forintösszeg (45,95 százalék); illetve nagyvállalkozás besorolást, ha az 250 fónél nagyobb és/vagy a mérlegföösszege meghaladja az 50 millió eurónak megfelelő forintösszeget (36,49 százalék).

A méret szerint megkülönböztetett csoportokat az elvárt szintnek megfelelő fizetési képesség jellemezte, elfogadható szintű likviditással és eladósodottsággal rendelkeztek. Ugyanakkor a pénzügyi mutatókat tekintve a tőkefeszültség és a sajáttőke-növekedési mutató vonatkozásában jelentős különbségek látha- tók a gazdasági társaságok méret szerinti csoportjai között.

A közepes méretű társaságból álló csoport jellemezhető a legkedvezőbb pénzügyi helyzettel, hatból három mutató esetében is a legjobb értékeket kapta. Egyedül a tőkefeszültség értéke esett kívül az elvárt tartományon.

A teljes sokaságon belül a mikroméretű társaságok rendelkeznek a legrosszabb likviditással, eladósodottsággal és tőkeellátottsággal, ugyanakkor tőkefeszültsége és jövedelmezősége a legjobb volt. A legrosszabb jövedelmezőséget a kisméretű gazdasági társaságok mutatták. A szélsőséges értékek kiszűrését követően ugyanakkor egy stabil pénzügyi helyzetü, alacsony jövedelmezőségü csoport látható.

A pénzügyi mutatók átlagos értékei a szélsőséges értékek kizárását követően a legtöbb esetben megváltoztak. A szélsőséges értékek nélküli sokaság méret szerint kialakított csoportjainak pénzügyi mutatói jelentősen köze- 


\section{A PÉNZÜGYI MUTATÓK ÁTLAGOS ÉRTÉKEI A TÁRSASÁGOK MÉRETE SZERINT CSOPORTOKBAN} A TELJES SOKASÁGRA SZÁMÍTVA

\begin{tabular}{|c|c|c|c|c|c|c|}
\hline $\begin{array}{c}\text { Méret szerinti } \\
\text { besorolás }\end{array}$ & $\begin{array}{l}\text { Likviditási } \\
\text { ráta }\end{array}$ & $\begin{array}{l}\text { Eladósodott- } \\
\text { sági mutató }\end{array}$ & $\begin{array}{l}\text { Tókefeszillt- } \\
\text { ségi mutató }\end{array}$ & $\begin{array}{l}\text { Tókeellá- } \\
\text { tottsági } \\
\text { mutató }\end{array}$ & $\begin{array}{c}\text { Sajáttóke- } \\
\text { növekedési } \\
\text { mutató }\end{array}$ & ROE \\
\hline Elvárt tartomány & $>1,0$ & $<0,5$ & $<1,0$ & $>0,5$ & $>1,0$ & $>0,0$ \\
\hline \multicolumn{7}{|l|}{ Mikro } \\
\hline Mutató értéke & 3,53 & 0,45 & 1,35 & 0,31 & 3,81 & 0,12 \\
\hline Tisztított mutató & 3,53 & 0,28 & 0,34 & 0,47 & 3,81 & 0,06 \\
\hline $\begin{array}{l}\text { Sokaságban } \\
\text { maradt (\%) }\end{array}$ & 100,00 & 91,18 & 84,62 & 94,12 & 100,00 & 69,23 \\
\hline \multicolumn{7}{|l|}{ Kis } \\
\hline Mutató értéke & 7,22 & 0,27 & 2,63 & 0,50 & 19,45 & $-0,07$ \\
\hline Tisztított mutató & 4,45 & 0,27 & 0,52 & 0,50 & 9,44 & 0,04 \\
\hline $\begin{array}{l}\text { Sokaságban } \\
\text { maradt (\%) }\end{array}$ & 91,40 & 100,00 & 87,10 & 100,00 & 93,81 & 59,14 \\
\hline \multicolumn{7}{|l|}{ Közepes } \\
\hline Mutató értéke & 12,34 & 0,22 & 1,57 & 0,57 & 27,13 & 0,03 \\
\hline Tisztított mutató & 3,45 & 0,22 & 0,49 & 0,57 & 6,01 & 0,03 \\
\hline $\begin{array}{l}\text { Sokaságban } \\
\text { maradt (\%) }\end{array}$ & 89,39 & 100,00 & 94,17 & 100,00 & 83,67 & 88,05 \\
\hline \multicolumn{7}{|l|}{ Nagy } \\
\hline Mutató értéke & 36,30 & 0,28 & 8,46 & 0,51 & 8,25 & 0,04 \\
\hline Tisztított mutató & 2,93 & 0,28 & 0,48 & 0,51 & 4,74 & 0,03 \\
\hline $\begin{array}{l}\text { Sokaságban } \\
\text { maradt (\%) }\end{array}$ & 95,29 & 99,62 & 84,58 & 100,00 & 96,62 & 90,12 \\
\hline $\begin{array}{l}\text { Összesen } \\
\text { sokaságban } \\
\text { maradt (\%) }\end{array}$ & 92,28 & 99,46 & 89,51 & 99,73 & 90,41 & 84,34 \\
\hline
\end{tabular}

Megjegyzés: Vastag betúvel emeltük ki azokat az értékeket, amelyeknél a tisztított sokaságban maradó elemek száma nem érte el a teljes sokaság területenkénti elemszámának 85 százalékát.

Forrás: az elemzett gazdasági társaságok számviteli beszámolói alapján, saját szerkeszzés 
ledtek egymáshoz. A tisztított sokaságokban minden csoportot már kedvező elfogadható tőkefeszültségi mutató jellemez, alacsony, de pozitív jövedelmezőség mellett. A tőkeellátottsági mutató esetében a mikroméretű társaságok által alkotott csoportok értékei nem érték el az elvárt szintet.

Az adatok arra hívják fel a figyelmet, hogy a társaságok pénzügyi mutatóit a méret önmagában nem határozza meg. A teljes sokaságban mért méretnagyság szerinti különbségek ugyanis a szélsőséges esetekre vezethetők vissza.

A közfeladat-ellátás szempontjából is megvizsgáltuk a csoportot. A közfeladatot ellátó állami tulajdonú gazdasági társaságokra sok esetben szigorúbb szabályok vonatkoznak, illetve a nyújtott szolgáltatás árazása során nem a piaci körülmények döntenek. Elemzésük lehetőséget nyújt a közfeladat-ellátás és a gazdálkodást jellemző pénzügyi mutatószámok közötti kapcsolatok azonosítására. Az elemzett szervezetek kétharmada (68,24 százaléka) látott el valamilyen közfeladatot. (Lásd 6. táblázat.)

A közfeladatot ellátó társaságokat alapvetően alacsonyabb likviditás jellemzi. A közfeladatot ellátók mérlegföösszeghez viszonyított alacsonyabb eladósodottsága és tőkeellátottsága a közfeladatot nem ellátókhoz képest a mérlegföösszeghez képest jelentősen nagyobb (több mint kétszeres) passzív időbeli elhatárolások arányára vezethető vissza. A társaságok fejlesztéseiket jelentős mértékben vissza nem térítendő támogatásból valósították meg, amely számviteli elszámolása szerint a paszszív időbeli elhatárolások között jelenik meg halasztott bevételként, míg az eszközoldalon megjelenő, a pályázat megvalósítása során beszerzett gépek, berendezések elszámolt értékcsökkenésével arányosan került visszaforgatásra. Így közgazdasági értelemben a vissza nem térítendő támogatásokból megvalósuló eszköznövekedésnek a passzív időbeli elhatárolások jelentik a tartós forrását.

A jövedelmezőség, ha kis mértékben is, de alacsonyabb a nem közfeladatot ellátó csoportban. Annak ellenére, hogy esetükben a hosszú távú fenntartható müködés saját forrásokból való biztosítása, valamint a tulajdonos részére biztosított bevétel az általános vállalati gazdaságtani szabályok szerinti követelmény.

A tisztítást követően a közfeladatot ellátó és nem ellátó gazdasági társaságok átlagos mutatóinak értékei között csak kismértékű különbség maradt. A szélsőséges értékek nélküli sokaság közfeladat-ellátás szerint kialakított csoportjait kedvező fizetési képesség és tőkeszerkezet jellemzi, alacsony jövedelmezőség mellett.

A sajáttőke-növekedési mutató elemzése a vizsgált 148 társaság vonatkozásában azt mutatta, hogy a gazdasági társaságok egy része (12 százalék) a gazdasági tevékenységének méretéhez képest súlyosan alultőkésített (a tőkeellátottsági mutató 0,1 alatti). Ez lehet annak a következménye, hogy a társaságot eleve csak a minimálisan szükséges jegyzett tőkével hozták létre és eredményágon sem növelte saját tőkéjét, vagy annak a következménye, hogy veszteséges gazdálkodás következtében felélte a saját tőkéjét. Az állami tulajdonú gazdasági társaságok alacsony sajáttőke-állománya komoly költségvetési kockázatot is hordoz, mivel ez azt jelenti, hogy veszteséges gazdálkodásuk esetén igen hamar bekövetkezhet az a helyzet, amikor az állami tulajdonosnak kell a saját tőkét visszapótolnia. A kockázatok csökkentésének igénye felveti a társasági portfóliótisztítás szükségességét, a nem életképes társaságok megszüntetését vagy átszervezését.

A korrigált mutatókkal végzett elemzés jól mutatta, hogy a mutatókészlet alkalmas volt a kiválasztott állami tulajdonú gazdasági társasági csoport gazdálkodásának, pénzügyi teljesítményének a leírására, mérésére. Ez alátámasztja, hogy a kialakított mutatók a közszférán belül széles körben alkalmazhatók. 
6. táblázat

\section{A PÉNZÜGYI MUTATÓK ÁTLAGOS ÉRTÉKEI A KÖZFELADAT-ELLÁTÁS SZERINT KIALAKÍTOTT CSOPORTOKBAN}

\begin{tabular}{|c|c|c|c|c|c|c|}
\hline Megnevezés & $\begin{array}{l}\text { Likviditási } \\
\text { ráta }\end{array}$ & $\begin{array}{l}\text { Eladósodott- } \\
\text { sági mutató }\end{array}$ & $\begin{array}{l}\text { Tökefeszillt- } \\
\text { ségi mutató }\end{array}$ & $\begin{array}{l}\text { Tókeellá- } \\
\text { tottsági } \\
\text { mutató }\end{array}$ & $\begin{array}{c}\text { Sajáttóke- } \\
\text { növekedési } \\
\text { mutató }\end{array}$ & ROE \\
\hline Elvárt tartomány & $>1,0$ & $<0,5$ & $<1,0$ & $>0,5$ & $>1,0$ & $>0,0$ \\
\hline \multicolumn{7}{|c|}{ Közfeladatot ellátók } \\
\hline Mutató értéke & 5,61 & 0,25 & 5,65 & 0,49 & 20,37 & 0,06 \\
\hline Tisztított mutató & 3,33 & 0,24 & 0,48 & 0,50 & 5,93 & 0,03 \\
\hline $\begin{array}{l}\text { Sokaságban } \\
\text { maradt (\%) }\end{array}$ & 95,62 & 99,60 & 87,32 & 99,60 & 90,32 & 85,28 \\
\hline \multicolumn{7}{|c|}{ Közfeladatot nem ellátók } \\
\hline Mutató értéke & 49,06 & 0,28 & 0,87 & 0,62 & 13,71 & $-0,06$ \\
\hline Tisztított mutató & 3,55 & 0,27 & 0,51 & 0,62 & 5,78 & 0,02 \\
\hline $\begin{array}{l}\text { Sokaságban } \\
\text { maradt (\%) }\end{array}$ & 85,41 & 99,15 & 94,25 & 100,00 & 90,60 & 82,30 \\
\hline $\begin{array}{l}\text { Összesen } \\
\text { sokaságban } \\
\text { maradt (\%) }\end{array}$ & 92,28 & 99,46 & 89,51 & 99,73 & 90,41 & 84,34 \\
\hline
\end{tabular}

Forrás: az elemzett gazdasági társaságok számviteli beszámolói, saját szerkesztés

PORTFÓLIÓKÉPZÉS

KLASZTERANALÍZISSEL

Az állami tulajdonú gazdasági társaságok esetében az elszámoltathatóság és a felelős vagyongazdálkodás egyik biztosítéka az érdemi tulajdonosi ellenőrzés (Domokos, 2019). A köztulajdonú vállalatok akkor tudják eredményesen betölteni társadalmi-gazdasági szerepüket, ha tulajdonosaik követendő stratégiát és világos teljesítménykövetelményeket szabnak. A célok elérését pedig az eredmények folyamatos monitorozásával es értékelésével mozdíthatják elő (Domokos, Várpalotai, Jakovác et al., 2016).
„Azoknál a tulajdonosi joggyakorlóknál” pedig, „amelyek több gazdasági társaság esetében is gyakorolják a tulajdonosi jogokat, célszerü megoldás lehet a portfóliómenedzsment kialakitása" (Boros, Gergő, Bándi et al., 2018 68. oldal). A portfólió a közgazdasági szakirodalom szerint az egyén vagy intézmény által tartott aktívák (eszközök, vagyon) halmazát jelenti. A portfólió menedzselése során pedig a vagyontartó diverzifikációt hajt végre ezért, hogy ezzel növelje a hozamot (Pearce, 1993). Ennek alapfeltétele a társaságok portfóliókba, a kezelésük szerint megkülönböztetett csoportokba sorolása.

A pénzügyi adottságok és teljesítmény szerinti megkülönböztetett kezelés támogatása 
érdekében kísérletet tettünk a 148 gazdasági társaság korrigált pénzügyi mutatói szerint viszonylag homogén csoportok, portfóliók képzésére. Homogén csoportnak tekintettük, ahol a csoporttagok jellemzőik alapján jobban hasonlítanak egymáshoz, mint más csoportok tagjaihoz.

A regressziószámítás során bebizonyosodott, hogy a társaságok mérete, közfeladatellátása és tevékenysége nem magyarázta a pénzügyi mutatók változását, ezért a portfólióképzés során elsődlegesen a pénzügyi jellemzők elemzése felé fordultunk. A portfóliók kialakításához a pénzügyi mutatóknál alkalmazott szélsőséges értékektől tisztított adatbázison - klaszteranalízist alkalmaztunk. A teljes sokaság minden adatának elemzését elvetettük, mert a kiugró tételek miatt a konvergenciafeltétel nem teljesült. A klaszterképzést az ötéves adatbázison és az utolsó, 2019. év adatain is elvégeztük.

A klaszterképzést a SAS Enterprise Guide szoftver alkalmazásával a Fastclus-eljárással az úgynevezett K-közép-módszer szerint végeztük, diszjunkt klaszterek kialakításával. A K-közép-módszer alkalmazása során első lépésként a szoftver kiválasztott $\mathrm{K}$ darab kezdő középpontot (centroid), az előzetesen megadott klaszterdarabszám alapján. Ebben az eljárásban ugyanis a $\mathrm{K}$ a klaszterek előzetesen meghatározott darabszámát jelenti. Ezt követően a modell minden adatpontot abba a klaszterbe sorolt, amelynek a középpontjához az a legközelebb esik, ezek a klaszterek jelentették a kiinduló klasztereket. Ezt követően a modell minden klaszter középpontját a klaszterhez rendelt pontok alapján frissíti. A hozzárendelési és frissítési lépéseket a modell felváltva folytatta (iterációk) egészen addig, amíg egyetlen pont sem váltott klasztert, vagy a középpontok változatlanok nem maradtak.

A klaszterképzéshez tényezőként beállított pénzügyi mutatók kiválasztásakor nem éltünk előzetes hipotézissel, hanem igyekeztünk a klaszterképzés során a lehető legtöbb tényezőt figyelembe venni. A variációk nagy számával próbáltuk a lehető legszorosabb összefüggést megtalálni. Kettő, három, illetve négy tényező megadásával négy, hat, illetve 10 klaszterből álló csoportosítással próbálkoztunk. A szoftveres klaszterezés során a 32 darab lehetséges változat közül hat szempont alapján került kiválasztásra a legjobb eredményt ígérő változat.

A validálás során alkalmazott szempontok a következők voltak. A klaszterközpontok klaszteren belül és az adatpontok a klaszterek között iterációnként mozognak, a konvergencia, a folyamatban az optimális állapot felé mozgást jelenti. A teljes konvergencia pedig akkor teljesül, ha egyetlen pont sem vált klasztert, vagy a középpontok sem változnak. A Fastclus-eljárás kellően jó klasztereket keres, ezért már a teljes konvergencia elérése előtt eredményt adhat (az iterációk leállnak), amennyiben a klasztermagok maximális relatív változása kisebb vagy egyenlő a konvergencia kritériummal. A képzett klaszterváltozatok között 11 esetben az eljárás nem érte el a teljes konvergenciát, ezért ezek a változatok elvetésre kerültek.

A sokaság szempontjából a Fastclus-eljárás elsődlegesen nagy adathalmazokkal (legalább 100 elemű sokaság) történő felhasználásra készült, kis adatállománynál az eredmények nagyon érzékenyek lehetnek az adatok sorrendjére. A képzett klaszterváltozatok közül, ezért a lehetséges érzékenység miatt 10 változatot elvetettünk.

A Fastclus-eljárásban a klaszterezés során a szoftver előállít egy úgynevezett köbklaszterezési kritériumot, amely a nyert klaszterváltozatot jellemzi. A 2 vagy 3-nál magasabb érték jó klasztereket, a 0 és 2 közötti érték lehetséges klasztereket, míg a nagy negatív érték kiugró értékre utal a klaszterekben. A képzett klaszterváltozatok közül 20 változat nem felelt meg a kritériumnak.

A jelzett három szürést követően hat klaszterváltozat maradt, amelyeket a kompaktság és a szeparáltság - mint a jó klaszter ismérvei - 
szempontjából értékeltük. A klaszterek egyik fontos jellemzője, hogy a klaszterek magjától az egyes értékek mekkora maximális távolságra helyezkednek el, amennyiben ez az érték alacsony, akkor az adott klasztert kompaktnak lehet nevezni. Egy változat elvetésre került, mert nem bizonyult kellően kompaktnak. A klaszterek másik fontos jellemzője, hogy a klaszterek legyenek minél inkább elkülöníthetők egymástól, azaz a klaszterközpontok minél nagyobb távolságra legyenek egymástól. Amenynyiben ez az érték magas, akkor az adott klaszter a hozzá legközelebb eső klasztertől szeparáltnak lehet nevezni.

A Pszeudo F-statisztika egy olyan a klaszterképzés minőségét jellemző mutató, amelynek magas értéke a klaszterek szeparáltságára utal, ekkor az egyes klaszterek jól elkülönülnek egymástól. A kompaktság és szeparáltság szempontjából, valamint a Pszeudo F-statisztika együttesen legjobb értékkel rendelkező verziót tekintettük az optimálisnak. A több té- nyező együttes hatásától várt több szempontú klaszterverziók nem adtak jó értéket, jellemzően a magasabb klaszterszámú, de kevesebb tényező figyelembevételével kialakított változatok érték el a jobb eredményt. A kiválasztási folyamatot a 2. ábra mutatja.

A validálási szempontok figyelembevételével a 2019. évi adatokat, a 148 gazdasági társaságot tartalmazó, 6 klaszteres, 2 tényezős (az eladósodottsági és a tőkefeszültségi mutatóra képzett) változat került kiválasztásra. A legjobb klasztert adó mutatók kiválasztását alátámasztotta, hogy e két mutató közötti kapcsolat érte el a legmagasabb regressziós és determinációs együttható értéket.

A klaszterek közül két-két klaszter adatai nagyon közel estek egymáshoz, illetve azok elemszáma csekély volt (négy és hat darab), ezáltal e két klaszter összevonásra került a szoftver által javasolt, hozzá jellemzőikben legközelebb álló klaszterrel. Így 4 klasztert kaptunk, amelyek adatait a 7. táblázat mutatja be.

\section{A PORTFÓLIÓKÉPZÉS FOLYAMATA}

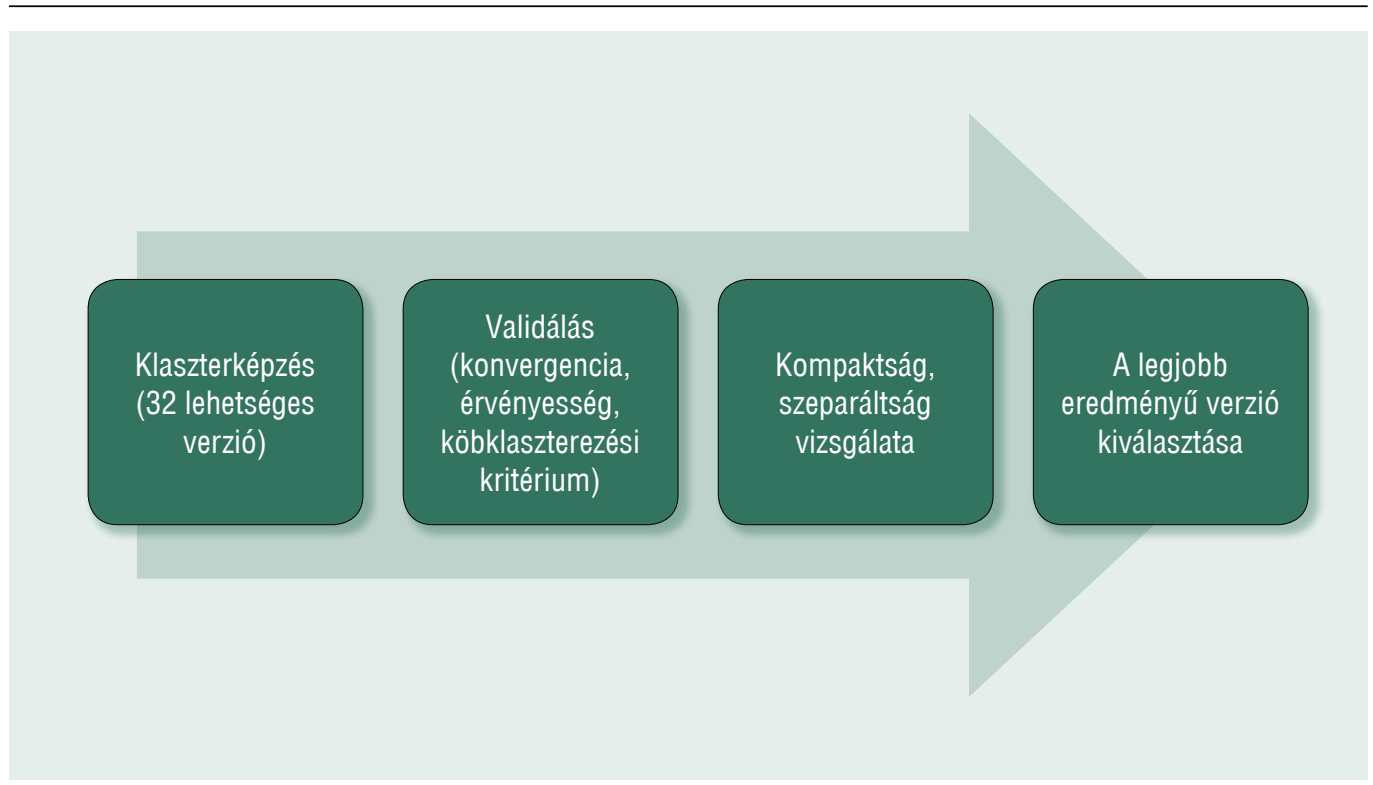

Forrás: saját szerkesztés 


\section{KÉPZETT KLASZTEREK JELLEMZŐI (2019)}

\begin{tabular}{|c|c|c|c|}
\hline \multirow{3}{*}{$\begin{array}{l}\text { Képzett klaszterek } \\
\text { sorszáma }\end{array}$} & \multirow{3}{*}{ Elemszám } & $\begin{array}{c}\text { Átlagos eladósodottsági } \\
\text { mutató }\end{array}$ & $\begin{array}{c}\text { Átlagos tốkefeszitiltségi } \\
\text { mutató }\end{array}$ \\
\hline & & \multicolumn{2}{|c|}{ Elvárt értêk } \\
\hline & & 0,5-nél kisebb & 1,0-nél kisebb \\
\hline 1. & 75 & 0,08 & 0,12 \\
\hline 2. & 33 & 0,25 & 0,52 \\
\hline 3. & 12 & 0,41 & 1,29 \\
\hline 4. & 28 & 0,75 & 2,45 \\
\hline
\end{tabular}

Forrás: SAS-szoftver, saját szerkesztés

A négy - pénzügyi mutatók alapján - kiválasztott klaszter esetében vizsgáltuk a csoportokon belüli méret, tevékenység és közfeladat-ellátással mutatkozó összefüggéseket is. Továbbá a kiválasztáskor mutatónként kiszűrt adatok is figyelembevételre kerültek a klaszterek részletes elemzése során. A klaszteranalízis eredménye alapján a négy klaszter jellemzői a következők szerint foglalható össze.

1. klaszter - a legjobb eladósodottsági és tőkefeszültségi kondícióval rendelkezők

A gazdasági társaságok döntő hányada, 51 százaléka itt található. Ezek a társaságok rendelkeztek a csoportok között a legjobb eladósodottsági és tőkefeszültségi mutatóval 2019-ben átlagosan. A csoport eladósodottsági mutatója a 0,08 átlagos érték, míg a tőkefeszültségi mutató a 0,12 átlagos érték körül szóródott, mely alacsony eladósodottságú és tőkefeszültségű csoportot képez. A klaszterben az eladósodottsági mutató 0 és 0,2 közötti értékeket vett fel, a tőkefeszültségi pedig 0 és 0,31 közötti értékeket. A többi mutató jellemzően az elvártnak megfelelő vagy a feletti értéket mutatott, és csak 0,04 és 0,12 százalék közötti arányban vett fel az elvárttól roszszabb értéket. A tokkeellátottság a csoportba tartozó 75 cég közül 9 kivételével elérte vagy meghaladta a már optimálisnak tekintett 0,5 értéket, a likviditási ráta három esetet kivéve, a sajáttőke-növekedési mutató pedig 5 esetet kivéve meghaladta az 1 értéket. A csoportra jellemző sajáttőke-növekedést támogatta a jó jövedelmezőség, amelyet a csoportra számított átlagos ROE 0,12 mutató értéke támaszt alá. A ROE csupán 12 esetben vett fel negatív értéket. A kiemelkedően erős likviditású pénzügyi tevékenységet folytatók is ebbe a klaszterbe kerültek.

Pénzügyi szempontból a csoportba tartozó társaságok mutatói jók, a társaságok pénzügyi gazdálkodása, likviditása, tőkeellátottsága megfelelö.

2. klaszter - elvárt tartományon belüli eladósodottsággal és tőkefeszültséggel rendelkezők

A gazdasági társaságok második legnagyobb hányada, 22 százalék, ide tartozik a 2019. évi adatok alapján. A csoport társaságai az elvárt értékeknél jobb átlagos eladósodottsági és tőkefeszültségi pénzügyi mutató értékekkel rendelkeznek, ugyanakkor értékeik elmaradnak az első csoportba tartozóktól. A klaszterben az eladósodottsági mutató 0,02 és 0,4 közötti értékeket vett fel, a tőkefeszültségi mutató pedig 
0,33 és 0,79 közötti értékeket, amely mindkét esetben megfelelőnek, az elvárt szinten belülinek mondható. A társaságok többségénél a likviditási és a sajáttőke-növekedési mutató is kedvező volt. A likviditási ráta három esetet kivéve, a sajáttőke-növekedési mutató pedig 1 esetet kivéve meghaladta az elvárt 1 értéket. Ugyanakkor a tőkeellátottság a cégek majdnem felénél (16 esetben) nem érte el a 0,5 értéket. Az elvárt érték alatti átlagos tőkeellátottság $(0,46)$ mellett azonban a ROE a 33 társaságból csupán 4 esetben vett fel negatív értéket, a társaságok működése jellemzően pozitív eredményességet mutatott.

A csoportba tartozó társaságok pénzügyi mutatói az elvárt szintet elérik, sőt jellemzően meg is haladják. A csoportban ugyanakkor már megjelennek tőkeellátottsági problémák, amelyek mellett azonban a társaságok működése még megfelel az általános gazdasági társaságoktól a pénzügyi szakirodalom szerint elvártnak.

3. klaszter - többnyire elfogadható eladósodottságú, de már az elvártnál rosszabb tőkefeszültségü társaságok

A sokaság legkisebb aránya, 8 százalék esett ebbe a klaszterbe. Az eladósodottsági mutató átlagát tekintve az elvárt értéken belül van, azonban 3 esetben már 0,55 és 0,58 közötti értéket vesz fel, ami már az elvárt tartományon kívül esik. A tőkefeszültségi mutató értéke két társaságot kivéve meghaladja az elvárt értékhatárt, az 1-et. A két kivétel is alulról közelíti az egyet a 0,82-es értékkel. A likviditás négy esetet kivéve megfelelőnek mutatkozik, a tőkeellátottság azonban figyelendő kategóriába esik e klaszter vonatkozásában, mert a mutató értéke 0,5 alatti értéket vett fel, 1 esetet kivéve, ahol 0,53-at. A sajáttőke-növekedési mutató minden esetben megfelelő értéket vett fel, átlagban 6,37 értéket ért el. A társaságok eredményessége az átlagos ROE 0,04 értéket mutatja.
A csoport tagjai döntően eladósodottsági problémával még nem bírnak, azonban eszközeiket már az elvártnál nagyobb arányban fedezik idegen tőkével. Az idegen tőke terheire, valamint az esetleges arány további növekedése a vállalkozás egyre erősebb függését jelentheti a külső finanszírozóktól. A saját tőke ennek ellenére bőven meghaladja a jegyzett tőkét, likviditásuk, eredményességük is elfogadható szintü.

4. klaszter - kedvezőtlen eladósodottsággal, tőkefeszültséggel és tőkeellátottsággal rendelkezők

A teljes sokaság közel ötöde, 19 százaléka tartozik ebbe a klaszterbe. Mind az átlagos eladósodottsági, mind az átlagos tőkefeszültségi mutató az elvárt tartományon kívül esett 2019ben. A csoportot átlag 0,75-ös eladósodottsági mutató és 2,45-ös tőkefeszültségi mutató jellemezte, amely körül a csoporttagok értékei szóródtak. Az értékek az elvártnál rosszabb eladósodottságot jeleztek. A kötelezettségek értéke meghaladta a saját tőke kétszeresét, amely a szakirodalom szerint elvárt érték duplája, illetve a tőkeellátottság - az átlagos 0,10-es értékű tőkeellátottsági mutató alapján - az idegentőke felé tolódott el. A részértékeket áttekintve ugyanez igaz ezekre a mutatókra, egy esetet kivéve, amikor bár az eladósodottsági mutató elvárt értéket vett fel, de a tőkefeszültség és a tőke-ellátottság is kedvezőtlen volt. A klaszteren belül továbbá 16 esetben a tőkefeszültség szélsőségesen rossz értéket vett fel, egy esetben pedig az alkalmazott módszertanból eredően negatív saját tőkére tekintettel érték nem került kiszámításra. A tőkeellátottsági mutató $-0,43$ és 0,32 közötti értékeket vett fel. A magas eladósodottsági mutató mellett ugyanakkor a likviditás közel a sokaság felében (46 százalékban) megfelelő volt. A sajáttőke-növekedési mutató 4 esetben volt az elvárt szint alatt. A ROE 4 esetben vett fel negatív értéket, ebből 3 esetben szélsőségesen rossz értéket. 
A csoport eladósodottsági problémával, alacsony sajáttőke-aránnyal, de még megfelelő likviditással és a csoport többségében - 81 százalékban - pozitív eredményességgel társul, amely a csoport vonatkozásában már erős tulajdonosi portfóliókontrollt igényel. Amennyiben a csoport mutatói több év távlatában sem javulnak, a társaságoknak finanszírozási problémái adódhatnak, és kötelezettségeik teljesítése veszélybe kerülhet annak további következményeivel.

A klaszterek tevékenység-szempontú elemzése alapján megállapítható, hogy a pénzügyi tevékenységet folytató társaságok pénzügyi mutatói a legkiemelkedőbbek, így az 1. klaszterbe kerültek besorolásra. Ugyancsak megfelelő pénzügyi mutatókkal rendelkeznek az erdőgazdaságok, a mezőgazdaság és halászatot folytató társaságok, melyek minden esetben az első két klaszterbe kerültek besorolásra. A legkedvezőtlenebb pénzügyi mutatókkal a projektmegvalósító szervezetek rendelkeznek, amelyek - egy kivétellel - a 4. klaszterbe kerültek. Érdemes még megjegyezni, hogy a humán-, illetve az információ, kommunikáció tevékenységet folytató társaságok jelentős többsége az első két klaszterbe került besorolásra, így kisebb részük rendelkezik rosszabb pénzügyi mutatóval.

A foglalkoztatottak létszáma és a klaszter csoportok közötti összefüggést vizsgálva figyelemre méltó, hogy a 10 főnél kisebb létszámmal rendelkező társaságok jellemzőn az 1 . klaszterbe kerültek, amely részben a tevékenységi körükkel is magyarázható (25,0 százaléka pénzügyi tevékenység). Valamint szintén az 1 . klaszterbe került a 250 fö feletti foglalkoztatott létszámmal rendelkező gazdasági társaságok közel fele.

A klaszterek és a közfeladat-ellátás összefüggésében kiemelhető, hogy amíg az 1. klaszteren belül a közfeladat-ellátók és nem ellátók aránya kiegyensúlyozott volt (51 százalék és 53 százalék), addig az összes közfeladat-ellátók 20,8 százalék a 4. klaszterbe került besorolásra. Ez az arány magasabb a közfeladatot nem ellátókénál, ezért a 4. klaszteren belül a legnagyobb a közfeladatot ellátók aránya (80,77 százalék).

A klaszterek méret szerinti elemzése azt mutatja, hogy a mikrovállalkozások, ahol alacsony a foglalkoztatottak száma az 1. klaszterbe kerültek. A közepes méretű gazdasági társaságok nagy aránya jó pénzügyi mutatókkal rendelkezett, 82,3 százaléka az első két klaszterbe került. A kis- és nagyméretű társaságok közel azonosan oszlottak meg a klaszterek között, azonban a 4. klaszterben a társaságok 50 százaléka nagyméretű volt.

A klaszterek részletes elemzésének eredménye alapján úgy gondoljuk, hogy a matematikai alapon kiválasztott klaszterek hasznos információval szolgálhatnak a tulajdonos részére egy jövőbeni portfóliókezelés szempontjainak kialakításához.

A klaszterek elemzése azonosított egy kiemelt figyelmet igénylő társasági kört, amelyet az elvárt feletti eladósodottság és kedvezőtlen tőkeellátottság jellemez. A csoportba tartozik a negatív, illetve 0,5 alatti sajáttőke-növekedési mutatóval rendelkező öt korlátolt felelősségű társaság közül négy. Ezek a társaságok a 4 . klaszterbe kerültek. A csoporttagok 81 százaléka közfeladatot lát el. Ezen szoros és folyamatos tulajdonosi kontrollt igénylő 4. klaszterbe tartozó társaságok között kockázati tényező volt a csoporttagok 36 százalékánál az alacsony (3-5 millió forint közötti) jegyzett tőke, 29 százalékánál a negatív vagy minimális időszaki adózott eredmény, 25 százalékánál a negatív vagy minimális eredménytartalék, míg a 32 százaléka a saját tőke dupláját meghaladó kötelezettségállománnyal rendelkezett.

Ezzel egy időben ugyanakkor kirajzolódott egy nagy tagszámú, 108 fös, a teljes elemzett társaság 73 százalékát kitevő csoport, amely gazdálkodását jellemző pénzügyi mutatói jók, likviditásuk erős, a tőkeellátottság az elvárt szintnek megfelel, jövedelmezőségük jellemző- 
en pozitív. Ezek a társaságok az 1. és 2. klaszterbe tartoztak. A csoport adatai nem utalnak kritikus gazdálkodási tényezőkre, kockázatokra.

A két csoport között azonosítható egy kis tagszámú csoport, ahol az eladósodottsági problémák megelőzésére kell a tulajdonosi kontrollnak koncentrálnia. Ide tartoznak a 3. klaszterbe sorolt társaságok. A csoporttagok jellemzően nem végeznek közfeladatot (66 százalék), vagyonkezelt eszközzel nem rendelkeztek. A három negatív jövedelmezőséggel rendelkező társaság egyike se látott el közfeladatot, ugyanakkor velük szemben indokolt lenne magasabb tőkearányos jövedelmezőségi követelményt támasztani, vagy megfontolni a társaságok megszüntetését vagy átszervezését.

\section{ÖSSZEGZÉS}

Napjainkban - a Covid-19-járványhullámok, valamint a világpiaci energiaárak változása jellemezte gazdálkodási közegben - a teljesít- ménymenedzsment, az alapos módszertani mérés kiemelt jelentőségű. Az Állami Számvevőszék stratégiai céljának tekinti a közpénz és közvagyon felhasználása során a teljesítménymérés érvényesülésének elősegítését és támogatását. A közszférában a teljesítménymenedzsment alkalmazását elősegíthetik a témában születő gondolatébresztő, tanácsadó anyagok. A tanulmányban bemutatott korrigált pénzügyi mutatók jól alkalmazhatók a többségi tulajdonú állami vagy önkormányzati tulajdonú gazdasági társaságok teljesítménymenedzsmentje keretében a pénzügyiteljesítmény-mérések támogatására. A klaszterképzés pedig a több társaság feletti tulajdonosi joggyakorlók részére nyújthat hasznos eszközt a társaságokon belüli portfóliók kialakításához, a társaságok portfoliómenedzsmentjének támogatásához. A tanulmánnyal az Állami Számvevőszék szakértői mind a nemzeti tulajdonú gazdasági társaságok, mind a tulajdonosi gyakorlók számára kívántak hasznos szempontokat, eszközöket kínálni.

\section{IRODALOM}

Boros A., Gergő J., BÁndi I., Kocsis E., HajDics A. A., Szólik E. (2018). Az állami vagyongazdálkodás, Nemzeti Közszolgálati Egyetem

Debreceni B. (2016). Klaszterezési módszerek minöségellenörzése, klaszterezési módszerek összehasonlitása. Miskolci Egyetem, Miskolc, http://midra.unimiskolc.hu/document/24470/19450.pdf

Domokos L., Nyéki M., Jakovác K., Németh E., Hatvani Cs. (2015). Kockázatelemzés és kockázatkezelés a közszférában és a közpénzügyi ellenőrzésben. Pénzügyi Szemle, 2015/1, https://www. asz.hu/hu/penzugyi-szemle/kockazatelemzes-eskockazatkezeles-a-kozszferaban-es-a-kozpenzugyiellenorzesben
Domokos L., VÁrpalotai V., Jakovác K., Németh E., Makкai M., Horváth M. (2016). Szempontok az állammenedzsment megújításához. Pénzügyi Szemle 2016/2, 185-204. oldal

Dомокоs L. (2019). Ellenörzés - a fenntartató jó kormányzás eszköze. Akadémiai Kiadó, Budapest

Domokos L., Wertherné Sz. D. (2020). A számvevőszéki teljesítmény mérésének modellje, a teljesítménymenedzsment fó területei. Pénzügyi Szemle 65 (1. különszám), https://doi.org/10.35551/PSZ_2020_k_1_1

Gyires B. (2012). Tananyagtár, 8. fejezet, Klaszteranalízis: Alapvető fogalmak és algoritmusok, On- 
line: https://gyires.inf.unideb.hu/KMITT/a04/ ch08.html

IvÁNYos J., SÁNDORNÉ K. É. (2016). A kockázatkezelés teljesítménymutatókon alapuló mérési és értékelési módszerei. Pénzügyi Szemle, 2016/2

KaISER T. szerk. (2014). Hatékony közszolgálat és jó közigazgatás-nemzetközi és európai dimenziók. Tanulmánykötet, Nemzeti Közszolgálati Egyetem, https:// docplayer.hu/175448-Hatekony-kozszolgalat-esjo-kozigazgatas-nemzetkozi-es-europai-dimenziokszerkesztette-kaiser-tamas.html

Pearce, D. W. szerk. (1993). A modern közgazdaságtan ismerettára. Budapest Közgazdasági és Jogi kiadó

Pulay Gy., Simon J. (2020).A közpénzügyi gazdálkodás makrogazdasági teljesítményének mérése, Pénzügyi Szemle, 65(1. különszám), https://doi.org/10.35551/PSZ_2020_k_1_2

Szakács G. (2012). Teljesitménymenedzsment.
Nemzeti Közszolgálati Egyetem, Közigazgatási Vezetői Akadémia

TAKÁcs A. (2015). Vállalatértékelés a magyar számviteli környezetben. SALDO

Veresné S. M. (2017). „Jó gyakorlatok” - Etikus vezetés, integritás és teljesítménymenedzsment a közszférában. Az Állami Számvevőszék és a Miskolci Egyetem közös konferenciája 2017. január 26.

Pécsi Tudományegyetem Közgazdaságtudományi Kar (2018). Vállalati Pénzügyek Kézikönyv. Pécs Tudományegyetem, Ulbert J. szerk., https://kktk.pte. hu/file/kiadvanyok/konyveink

SAS/STAT Software FASTCLUS Procedure, Online: https://support.sas.com/rnd/app/stat/ procedures/fastclus.html

SAS/STAT ${ }^{\circledR} 13.2$ User's Guide The FASTCLUS Procedure, Online: https://support.sas.com/documentation/onlinedoc/stat/132/fastclus.pdf 